\title{
RESEARCH OF SOCIOCULTURAL FAMILY VALUE IN THE CONSCIOUSNESS OF MILITARY UNIVERSITY CADETS
}

Лен А.А., Торкунова О.И., Филоненко Л.В.

\section{ИССЛЕДОВАНИЕ СОЦИОКУЛЬТУРНОЙ ЦЕННОСТИ СЕМЬИ В СОЗНАНИИ КУРСАНТОВ ВОЕННОГО ВУЗА}

\begin{abstract}
The article examines the sociocultural value of the family in the minds of military university cadets in the light of changes that have occurred in the marriage and family sphere in modern Russian society. The first part of the article reveals relevance of this problem, content of terminal values, their classification and characteristics of individual groups. The article highlights some trends that occurred in the public consciousness of the late XX - early XXI centuries concerning the values of the marriage and family sphere. To get a deeper insight into the nature of this problem, the authors studied many works, compared the leading scientific approaches of scientists in the study of terminal values. The article examines theoretical ideas about family and marriage relations and the results of empirical research of social and cultural family values in the minds of students in the framework of teaching at the Department for military and political work, Russian Air Force Military Educational and Scientific Center "Air Force Academy "Professor N.E. Zhukovsky and Major Y.A. Gagarin". The authors provide data from the methods and conduct a detailed qualitative analysis of the level of lifemeaning orientations and the most significant terminal values of cadets. The educational impact on cadets in order to form the value of the family in a military University is complex. The content of training programs in the disciplines "Psychology", "Psychology and Pedagogy", "Personnel Management in the armed forces of the Russian Federation" is aimed at solving this problem. The article makes an important conclusion that the training of cadets for family life is a significant part of military-political work in a military university, and the adjustment and formation of terminal values of young people in accordance with socially significant values is achievable with a systematic, purposeful psychological and pedagogical process of training cadets for marital and family relationship.
\end{abstract}

Keywords: marital and family relationship, happy family life, sociocultural value, cadets' vocational training, process of cadets' training for marital and family relations.

About the authors: Len Angela Alexandrovna, ORCID: 0000-0003-3606-8130, Ph.D., Military Educational and Scientific Centre of the Air Force N.E. Zhukovsky and Y.A. Gagarin Air Force Academy, Voronezh, Russia,
Аннотация. В статье рассматривается социокультурная ценность семьи в сознании курсантов военного вуза в свете изменений, произошедших в брачно-семейной сфере в современном российском обществе. В первой части статьи раскрывается актуальность данной проблемы, содержание терминальных ценностей, их классификация и характеристика отдельных групп. В статье выделены некоторые тенденции, произошедшие в общественном сознании конца XX - начала XXI веков, касающиеся ценностей брачно-семейной сферы. Чтобы глубже проникнуть в природу данной проблемы, было изучено множество трудов, сопоставлены ведущие научные подходы ученых в исследовании терминальных ценностей. В статье рассматриваются теоретические представления о семейно-брачных отношениях и результаты эмпирического исследования социокультурной ценности семьи в сознании курсантов в рамках преподавания дисциплин кафедры военнополитической работы Военного учебно-научного центра Военно-воздушных сил «Военно-воздушной академии имени профессора Н.Е. Жуковского и Ю.А. Гагарина». Приводятся данные методик, осуществлен подробный качественный анализ уровня смысложизненных ориентаций, наиболее значимых терминальных ценностей курсантов. Воспитательное воздействие на курсантов с целью формирования ценности семьи в военном вузе носит комплексный характер. На решение данной проблемы направлено, в том числе, содержание программ обучения дисциплин «Психология», «Психология и педагогика», «Работа с личным составом в ВС РФ». В статье делается важный вывод о том, что подготовка курсантов к семейной жизни является значимой составной частью военно-политической работы в военном вузе, а корректировка и формирование терминальных ценностей молодежи в соответствии с общественно значимыми ценностями возможны при планомерном, целенаправленном психолого-педагогическом процессе подготовки курсантов к семейно-брачным отношениям.

Ключевые слова: семейно-брачные отношения; счастливая семейная жизнь; социокультурная ценность; профессиональная подготовка курсантов; процесс подготовки курсантов к семейно-брачным отношениям.

Сведения об авторах: Лен Анжела Александровна, ORCID: 0000-0003-3606-8130, канд. пед. наук, Военный учебно-научный центр ВBC «Военно-воздушная академия им. профессора Н.Е. Жуковского и Ю.А. Гагарина», г. Воронеж, Россия, angelaplatonova@mail.ru; 
Torkunova Olga Ivanovna, ORCID: 0000-0001-77625971, Ph.D., Military Educational and Scientific Centre of the Air Force N.E. Zhukovsky and Y.A. Gagarin Air Force Academy, Voronezh, Russia, bolmari@yandex.ru; $\quad$ Filonenko Lyudmila Vladimirovna, ORCID: 0000-0002-0995-6127, Ph.D, Military Educational and Scientific Centre of the Air Force N.E. Zhukovsky and Y.A. Gagarin Air Force Academy, Voronezh, Russia, fil_1@mail.ru
Торкунова Ольга Ивановна, ORCID: 0000-0001-77625971, канд. психол. наук, Военный учебно-научный центр ВВС «Военно-воздушная академия им. профессора Н.Е. Жуковского и Ю.А. Гагарина», г. Воронеж, Россия, 2bolmari@yandex.ru; Филоненко Людмила Владимировна, ORCID: 0000-0002-0995-6127, канд. пед. наук; Военный учебно-научный центр ВВС «Военно-воздушная академия им. профессора Н.Е. Жуковского и Ю.А. Гагарина», г. Воронеж, Россия, fil_1@mail.ru

Nowadays modern education system has very important purpose. Its feature is orientation to formationof cadets' personality, particularly cadets'sociocultural valuesduring vacation in the military university, besides subjects studying [3]. Currently significant body of knowledge is built up in the sphere of psychology and family sociology $[2 ; 8 ; 14 ; 16]$.Articles, written by N.G. Markovskaya, M.S. Matskovskiy, S.Y. Nikolayeva, etc, are dedicated to psychological health of the family and family values mainstreaming during students vacation $[10 ; 11 ; 13]$.

Sociocultural family value formation during educational process of military universities often occurs under the influence of outdated customs and traditions, foreign pedagogical experience that does not conform to Russian cultural specificity, new social, political, economic demands of both world and modern Russian society. This contradiction confirms relevance of the chosen theme and demonstrates a need for domestic practice-oriented development, aiming at elaboration of sociocultural values necessary for Russian society, including happy family life values of young people.

We will try to highlight trends related to values of marital and family sphere that occurred in the public consciousness of the late XX - early XXI centuries. One of the most obvious trends is marriagenorm exception or restriction in the individual life. People do not deny it from the legal or moral and psychological point of view, but they readily ignore this norm in their own behavior. Significant result of retreat from legal recognizing marriage as a social norm is the negative or utmost restraint sexual partners' attitude towards childbirth.

Informal family successfully competes with formal one in the Russian society, and this trend can be considered relatively recent. This trend has a following feature: if the informal family was started in the middle of the previous century, it caused negative public opinion. Behavior of the woman who dared to cohabit with a man that had already been married or were just going to divorce was evaluated especially negatively [1].

According to L.V. Kartseva's words, any partnership in modern Russian society is quite liberally evaluated: between complete neutrality and this or that degree of aversion. More and more people realize the fact that emergence of such unions has objective basis - individual's desire to have family, home, children and be happy among people whom he loves and who love him. Divorce is still one of the most popular ways to solve intra-family conflicts in Russian society. On the one hand, it is a regulator of individual's psychologic wellbeing, but on the other hand, it has a deforming influence on society marital structure. Significant disadvantage of divorce is its negative relation to marriage and fertility. Firstly, people marry again very reluctantly after divorces. Secondly, divorce and childbirth are mutually exclusive concepts. Society that is striving to avoid depopulation or reduce its destructive capacity consequently should impede easy and fast getting divorced [7].

Russians have controversial attitude towards children. Children get love, care and are brought up in accordance with modern ideas of public needs and social realities. Parents sacrifice their prosperity for children, suffer pecuniary and moral losses. People want to have more than few do and less than multiply children. Both formal and informal families have children.

S.V. Morozova and Z.A. Shakurova note that moral reference point's absence and great involvement of studying young people in wide range of market relations affect spiritual development of young people, their terminal values [12].

In the view of I.P. Istomina, modern teacher have to solve educational problems that are socially significant for the present and future generations [5].

According to the research by I.P. Istomina and I.D. Mehdieva, the most effective work with cadets' families aimed at the problems of education and development is psychology-pedagogy support of the family [6].

In Russian society as well as in many Western countries family is increasingly popular as a way to release individual-psychological tension than as social livelihoods. Individually personal family functions are 
carried out much more than social ones. For a person they become more important than intra-group functions directed on aggregate targets and requirements realization by a family group. However, realization efficiency of this group of functions is a measure, which determines person's degree of interest in family life. They make family universal forevery member of it. If a person gets love, support, understanding, sympathy and joy of communication in the family, he strives to be member of it, and if it does not happen, family falls apart.

Socio-economic crisis caused a tendency of deliberate childbirth restriction to one or maximum two children along with the persistent need for two or more ones. Present historical period is remarkable for the fact that informal families do not face problems with childbirth process, except for the children counting. Real number of children is generally less than a perfect one, but in case of informal families, this gap is bigger.

National values remain in the intellectual elite consciousness in multi-ethnic society. Mass consciousness is characterized by separation from traditions, increased orientation to pan-European values and western mindset, marked by ethnic factor is inferior to socio-economic one. There is the same trend in marital and family sphere. Marriage, child-rearing, leadership in the family group, lifestyle, etc., that are important phenomenons of marital and family relationship, less and less depend on ethnocultural traditions, but increasingly on the individually-personal features.

Gender researches showed that working mother is more respected by children, less oriented to extra patronizing and pays more attention to development of the child. In addition, conjugal relations significantly improve in families with working women. However, one of the most important problems of this model is family responsibilities redistribution in accordance with woman's new professional role. Active participation in family problems and child rearing by a man must not take the form of help - it has to be responsibilities and duties sharing.

Service member personality development includes new social roles (husband, father) exploration. Development level of such values as responsibility and passionarism supports man's active participation in the family and children upbringing [9].

Men and women's roles become equal, symmetrical, involving both of family and professional functions. Proponents of this family relationship model insist on the socio-normative processing of this roles model. In this context legislative framework and socio-economic policy, that provides the opportunity to combine these roles for both of the spouses, are necessary [15].

Due to the relevance of the chosen theme, we have conducted a study of sociocultural family value in MESC AF "AFA" cadets' consciousness during educational process within the framework of the teaching "Psychology and pedagogy" and "Personnel work in AF of RF" courses in 2017-2019. 1980 participants, cadets of the $4^{\text {th }}$ and $5^{\text {th }}$ year, were involved. $30 \%$ of them had already started a family. According to the results of the study, $70 \%$ of cadets' answers were related to their parents' families, the member of which they were. $76 \%$ of respondents were from nuclear families, $23 \%$ - from single-parent families and $1 \%$ of respondents did not have parents and were brought up in the state institutions.

We used a method of values orientation research (M. Rokeach). Furthermore, cadets answered the questions about their intention to start a family in the next 5 years, number of children they would like to have, significance of the family to the modern society and them personally. Individual values hierarchy, that was drawn up in accordance with the result of the study, was split into 3 equal groups: preferred, significant values; indifferent, oblivious values; unacceptable, insignificant values.

In the article, our purpose is reflecting the study results, related to values of family life, so we will pay attention on them. Terminal values are those ones, which apply to life goals that the person plans to achieve during his life. Person generally has a set of livelihoods benchmarks, which is usually a multi-level system of goals he aims to achieve; they determine the purpose of his life. Both goals and behavior motives can have a rank, position relative to each other that depends on their significance and life perspectives. Happy family life is one of the terminal values.

The first question was as follows: "How well-ordered is your family-life? Evaluate its quality". $92 \%$ of cadets set rank 13-18 (insignificant). In our view, this is because for cadets happy family life is not associated with parents' family, but is considered as the absence of marital relationship. $12 \%$ of proponents set rank 7-12, that means indifferent.

We payed bigger attention to married cadets' answers. There is an interesting fact that $30 \%$ of cadets are married from several months up to 3 years, but $25 \%$ evaluate family life as insignificant or unacceptable, that must be connected with bad preparation to the family life, difficulties of marriage first years. As part of the study individual counselling revealed that almost a half of married cadets were about to divorce and $18 \%$ considered their family life to be a mistake and referred to the following reasons: "dated for too short time", 
"did not know each other enough", "had different values and views", "did not have ehough trust and mutual understanding". The cadets blamed their spouses to be too dependent on parents' opinion (especially mothers'). The next reason of disharmonious relationship was jealousy. $10 \%$ of cadets had children, $4 \%$ had married a woman with a child. Families with the children set a low rank (15-18), too, because they considered their family to be far from the value they had wished to realize. It is hard to say how much youthful high spirits influenced happy cadet's life evaluation, but it is paradox that young men feel themselves happy neither in relationship with the person they love nor in parenthood even during the first years of the marriage.

To answer the second and third questions (In what order would you set these values if you were a person you had dreamt to be? How do you think a perfect person would do it?) $100 \%$ of cadets set happy family life among significant values (rank 4-6). However, the answers to the forth question (How do you think most people would do it?) were divided into two groups: $78 \%$ of cadets set the high rank (3-6), but $32 \%$ set it to be indifferent (rank 7-10). There were not low ranks.

Almost all of the cadets expressed their intension to start a family in the next 5 years, have two or more children. We offered married cadets to write a small "Parent essay" in order to analyze the family values and gave them the following plan:

1. How do you understand the term of patriarchal and egalitarian family? What was the family that brought you up?

2. How do you think man's educational influence on the child differs from the woman is one? List the features of both of them.

3. What is mother's pedagogical role in raising a daughter? A son?

4. What is father's pedagogical role in raising a daughter? A son?

5. What do you like and do not like about your mother as a parent?

6. What do you like and do not like about your father as a parent?

7. How do you imagine the perfect parents? Do you consider yourself to be a perfect parent? List the most important features of the perfect mother and father. For example, how should they look like; what should they be able to do; how should they refer to their spouse; what character should they have; how, where and whom should they spend their free time with?

After that the cadets were split into small groups with 3-5 people and compared their essays, revealing maximal matches and differences. Every small group introduced results about the whole group. They compared and generalized. This exercise helped the cadets to realize and correct the family values in present and future.

Many cadets marked their lack of knowledge about family relationship psychology and wished it to be a special course in the military university education program.

To sum up, we give examples of cadets' answers to the question about the family value in their life:

- It is the basic core of person's life, where you are accepted who you are, and it makes you a better person.

- I think, people refer to starting a family in different ways: high-developed areas (like Moscow) are oriented to European values, so families are started for mercenary and career reasons there, but more respectful relationship to such family value as love and loyalty remains in the majority of Russian area. I refer myself to the last group.

- First, everybody needs a family for the childbirth child rearing, and only happy families can and must have children and bring them up.

- Most of people want to have a family, there is nothing more significant than family, and a service member always protects his family like his Motherland.

To sum up, the family as a small group and social "clothes" of the individual is not threatened. Happy family life as the terminal value is still significant for the young generation. Modern family, that is the most important social environment for person developing and the basic institution of psychological support and education, provides not only social demography, but developing special way of thinking, values, relationship and lifestyle besides. Cadets preparing to the family life is a significant part of military-political work of the military university. Specially organized pedagogical work, implemented during the vacation [4], terminal values developing and correction in accordance with socially significant values is possible with orderly, purposeful psychology-pedagogical process of cadets training for marital and family relations.

\section{References}

1. Volzhina, O.I. (2002). Sem'ya kak sotsiokul'turnaya tsennost': dis. ... d-ra sotsiol. nauk. Moscow. (in Russ.).

2. Egides, A.P. (2006). Brak bez braka, ili Uchebnik semeinykh otnoshenii. Moscow. (in Russ.). 
3. Ibragimova, L.A., \& Ganieva, E.A. (2016). Logika organizatsii i provedeniya proektno-issledovatel'skoi deyatel'nosti s uchashchimisya v obshcheobrazovatel'nom uchrezhdenii. Obshchestvo: sotsiologiya, psikhologiya, pedagogika, (2). 128-134. (in Russ.).

4. Ibragimova, L.A., \& Isupov, P.V. (2018). On the problem of emotional regulation among middle level medical staff. Bulletin of Nizhnevartovsk State University, (2). 27-33. (in Russ.).

5. Istomina, I.P. (2016). Training bachelor students for future work in the field of moral and spiritual education. Bulletin of Nizhnevartovsk State University, (4). 8-24. (in Russ.).

6. Istomina, I.P., \& Mekhdieva, I.D. (2017). Sotrudnichestvo obrazovatel'noi organizatsii s sem'yami obuchayushchikhsya, kak uslovie dukhovno-nravstvennogo vospitaniya podrastayushchego pokoleniya Rossii. Mir nauki, 5(2). 20-20. (in Russ.).

7. Kartseva, L. V. (2001). Sem'ya v usloviyakh transformatsii rossiiskogo obshchestva: Teoreticheskaya model' i empiricheskaya real'nost': dis. ... d-ra sotsiol. nauk. Kazan'. (in Russ.).

8. Kurtysheva M.A. (2007). Kak sokhranit' psikhologicheskoe zdorov'e sem'i. St. Petersburg. (in Russ.).

9. Len, A.A., Strebkova, I.N. (2019). Developing responsible and passionate attitude of military academy cadets to future professional activities. Bulletin of Nizhnevartovsk State University, (1). 72-79. (in Russ.).

10. Markovskaya, N.G. (1990). Mesto sem'i v sisteme tsennostnykh orientatsii lichnosti: avtoref. dis. ... kand. sotsiol. nauk. Moscow. (in Russ.).

11. Matskovskii, M.S., \& Bodrova, V.V. (1990). Tsennost' sem'i v soznanii razlichnykh sloev naseleniya. In Sem'ya v predstavleniyakh sovremennogo cheloveka. Moscow. (in Russ.).

12. Morozova, S. V. (2003). Tsennostnye orientatsii studentov Yuzhno-Ural'skogo universiteta. In Ezhegodnik Rossiiskogo psikhologicheskogo obshchestva: materialy 3-go Vserossiiskogo s"ezda psikhologov, 5. St. Petersburg. 482-485. (in Russ.).

13. Nikolaeva, S.Yu. (2003). Aktualizatsiya tsennostei sem'i v protsesse obucheniya studencheskoi molodezhi. In Ezhegodnik Rossiiskogo psikhologicheskogo obshchestva: materialy 3-go Vserossiiskogo s"ezda psikhologov. 6. St. Petersburg. 95-97. (in Russ.).

14. Ovcharova, R.V. (2003). Psikhologicheskoe soprovozhdenie roditel'stva. Moscow. (in Russ.).

15. Torkunova, O.I., \& Mashin, V. N. (2015). Transformatsii reproduktivnykh ustanovok v sfere obshchestvennogo soznaniya Adaptatsionnye mekhanizmy i praktiki v transformiruyushchikhsya obshchestvakh: materialy tret'ei mezhdunarodnoi nauchno-prakticheskoi konferentsii. Voronezh. 61-64. (in Russ.).

16. Shneider, L.B. (2000). Psikhologiya semeinykh otnoshenii: kurs lektsii. Moscow. (in Russ.).

\section{Литература}

1. Волжина О.И. Семья как социокультурная ценность: дис. ... д-ра социол. наук. М., 2002. 312 с.

2. Егидес А.П. Брак без брака, или Учебник семейных отношений. М: АСТ-ПРЕСС КНИГА.2006. 336 с.

3. Ибрагимова Л.А., Ганиева Э.А. Логика организации и проведения проектно-исследовательской деятельности с учащимися в общеобразовательном учреждении // Общество: социология, психология, педагогика. 2016. №2. С.128-134.

4. Ибрагимова Л.А., Исупов П.В. К проблеме эмоциональной регуляции среднего медицинского персонала // Вестник Нижневартовского государственного университета. 2018. №2. С. $27-33$.

5. Истомина И.П. Подготовка будущих бакалавров педагогического образования к профессиональной деятельности в области духовно-нравственного воспитания обучающихся // Вестник Нижневартовского государственного университета. 2016. №4. С. 18-24.

6. Истомина И.П., Мехдиева И.Д. Сотрудничество образовательной организации с семьями обучающихся, как условие духовно-нравственного воспитания подрастающего поколения России // Мир науки. 2017. T. 5. №2. С. 20-20.

7. Карцева Л. В. Семья в условиях трансформации российского общества: Теоретическая модель и эмпирическая реальность: дис. ... д-ра социол. наук. Казань, 2001. 609 с.

8. Куртышева М.А. Как сохранить психологическое здоровье семьи. СПб: Питер, 2007. 288 с.

9. Лен А.А., Стребкова И.Н. Формирование ответственного и пассионарного отношения курсантов военного вуза к будущей профессиональной деятельности // Вестник Нижневартовского государственного университета. 2019. №1. С. 72-79.

10. Марковская Н.Г. Место семьи в системе ценностных ориентаций личности: автореф. дис. ... канд. социол. наук. М., 1990. 23 с.

11. Мацковский М.С., Бодрова В.В. Ценность семьи в сознании различных слоев населения // Семья в представлениях современного человека. М.: Наука, 1990. 234 с.

12. Морозова С. В. Ценностные ориентации студентов Южно-Уральского университета // Ежегодник Российского психологического общества: материалы 3-го Всероссийского съезда психологов. Т. 5. СПб., 2003. C. $482-485$.

13. Николаева С.Ю. Актуализация ценностей семьи в процессе обучения студенческой молодежи // Ежегодник Российского психологического общества: материалы 3-го Всероссийского съезда психологов. Т. 6. СПб., 2003. С. 95-97.

14. Овчарова Р.В. Психологическое сопровождение родительства. М.: Изд-во Института Психотерапии, 2003. 319 c. 
15. Торкунова О.И., Машин В. Н. Трансформации репродуктивных установок в сфере общественного сознания Адаптационные механизмы и практики в трансформирующихся обществах: материалы третьей международной научно-практической конференции. Воронеж: ВГПУ, 2015. С. 61-64.

16. Шнейдер Л.Б. Психология семейных отношений: курс лекций. М.: ЭКСМО-Пресс, 2000. 512 с.

Len A.A., Torkunova O.I., Filonenko L.V. Research of sociocultural family value in the consciousness of military university cadets // Вестник Нижневартовского государственного университета. 2021. № 1(53). С. 18-23. https://doi.org/10.36906/2311-4444/21-1/03

Len, A.A., Torkunova, O.I., \& Filonenko, L.V. (2021). Research of Sociocultural Family Value in the Consciousness of Military University Cadets. Bulletin of Nizhnevartovsk State University. (1(53)). 18-23. https://doi.org/10.36906/23114444/21-1/03 